\title{
MEOTTOMYCES DISSIMULANS (AGARICALES, BASIDIOMYCOTA), NEW FOR POLAND
}

\author{
MareK HaLAma ${ }^{1}$ \& Ryszard RUtKowsKi
}

\begin{abstract}
This paper reports the first sites of Meottomyces dissimulans (Berk. \& Broome) Vizzini in Poland. About a dozen basidiomata in all stages of development were observed in poplar and alder-willow thickets. The macro- and micromorphological characters of the Polish specimens are described and illustrated, and the distribution of the species in Poland is given.
\end{abstract}

Key words: distribution, micromorphology, Phaeogalera dissimulans, Phaeogalera oedipus, Polish mycobiota

Marek Halama, Museum of Natural History, Wroctaw University, ul. Sienkiewicza 21, 50-335 Wrocław, Poland; e-mail: marek.halama@uwr.edu.pl

Ryszard Rutkowski, ul. Wspólna 194, 34-331 Świnna, Poland

\section{INTRODUCTION}

The genus Meottomyces Vizzini includes saprotrophic fungi occurring in the hemiboreal-temperate zone of the Northern Hemisphere. Members of the genus are characterized by their small to medium-size basidiomata with a viscid, hygrophanous and glabrous pileus (except for vanishing veil fragments over marginal area), often with an olivaceous tinge. The lamellae are adnate, subdistant and finally brown-ochre in color. The stipe has an annulate zone. Species of Meottomyces produce smooth (in SEM), ellipsoid to phaseoliform (in side view) basidiospores with a small germ pore. They possess clavate-elongate cheiloleptocystidia and form clamp-connections. There are three well recognized Meottomyces species worldwide, one of which, M. dissimulans (Berk. \& Broome) Vizzini, occurs in Europe (Smith \& Hesler 1968; Vizzini 2008; Noordeloos 2011). Berkeley and Broome described the species in 1882 and gave it the scientific name Agaricus dissimulans Berk. \& Broome; since then this fungus has been placed in various genera, including Dryophila (Kühner \& Romagnesi 1953), Pholiota (e.g., Smith \& Hesler 1968; Ludwig 2001; Gminder 2003), Phaeogalera (Ro-

\footnotetext{
1 Corresponding author
}

magnesi 1980; Holec 2003; Vizzini et al. 2006) and Hemipholiota (Bon 1986). The taxonomic position of Agaricus dissimulans was a matter of much controversy in the past, until modern molecular studies suggested its placement within a separate genus (e.g., Moncalvo et al. 2002; Garnica et al. 2007) and Vizzini (2008) placed the species in a newly described genus, Meottomyces. The erection of the new genus was also supported by recent phylogenetic analyses by Petersen et al. (2010).

In Europe, Meottomyces dissimulans is noted from various hardwood forests and woodlands. It is often reported from riparian plant communities of the Alno-Padion, Alnion incanae and Salicion albae associations with humus-rich soil, along streams and rivers. It usually grows on fallen or decayed (mushy) leaves, but it is also noted from soil, branches, twigs, strongly decayed stumps or wood chips (Legon 2013 and references therein). Rare records of the species from 'burnt ground' and an 'old railway sleeper' are also known (Vizzini et al. 2006; Legon 2013). A rather broad spectrum of plants have been signalled as possible hosts for $M$. dissimulans. It is on record from a long list of deciduous trees: Acer campestre L., A. negundo L., A. pseudoplatanus L., Aesculus sp., Alnus 
glutinosa (L.) Gaertn., A. incana (L.) Moench, Betula pendula Roth, Carpinus betulus L., Cornus sp., Corylus sp., Crataegus sp., Fagus sylvatica L., Fraxinus excelsior L., Malus sylvestris (L.) Mill., Populus $\times$ canadensis Moench, Populus sp., Populus tremula L., Quercus sp., Salix caprea L., S. fragilis L., Salix sp., Sorbus aria (L.) Crantz, Tilia sp., Ulmus minor Mill. and Ulmus sp. (e.g., Kalamees 1985; Vizzini et al. 2006; Legon 2013). M. dissimulans is exceptionally reported as growing on coniferous [Cedrus sp., Larix sp., Picea abies (L.) H. Karst., Pinus sylvestris L.] or herbaceous debris (e.g., Carex pendula Huds., Phyllitis scolopendrium (L.) Newman and indet. Poaceae) (Marchand 1980; Vizzini et al. 2006; Legon 2013). In Africa, M. dissimulans was reported on indeterminate moist plant debris and soil under Pinus maritima Mill. (Malençon \& Bertault 1970; Moreau 2009).

In Europe, $M$. dissimulans is distributed over most of the continent. It has been recorded from a number of European countries, including Austria, Belgium, the Czech Republic, Denmark, England, Estonia, Finland, France, Germany, Greece, Hungary, Ireland, Italy, Latvia, Liechtenstein, Luxembourg, Montenegro, the Netherlands, Norway, Portugal, Romania, Scotland, Slovakia, Spain, Sweden and Switzerland (e.g., Kalamees 1985; Hausknecht 1992; Rald 1992; Ortega \& EsteveRaventós 1998; Holec 2003; Nagy 2004; Onofri 2005; Vizzini et al. 2006; Walleyn et al. 2006; Courtecuisse \& Duhem 2007; Tholl 2010; Vesterholt 2012; Legon 2013; Hagara 2014). Noordeloos (2011) stated that $M$. dissimulans is a common species, but it appears not to be really frequent anywhere, except for the Netherlands where in general it is moderately common (Noordeloos 1999) and Great Britain where it is known from over 120 records (Legon 2013). Meottomyces dissimulans is on red lists of fungi of the Czech Republic, Denmark, the Netherlands and Switzerland (Antonín et al. 2006; Senn-Irlet et al. 2007; Arnolds \& Veerkamp 2008; Anonymous 2012). Although fructifications of $M$. dissimulans are spread in the period from January to December, the available data indicate that the great majority of finds are made in winter and early spring (December to April) (Legon 2013).

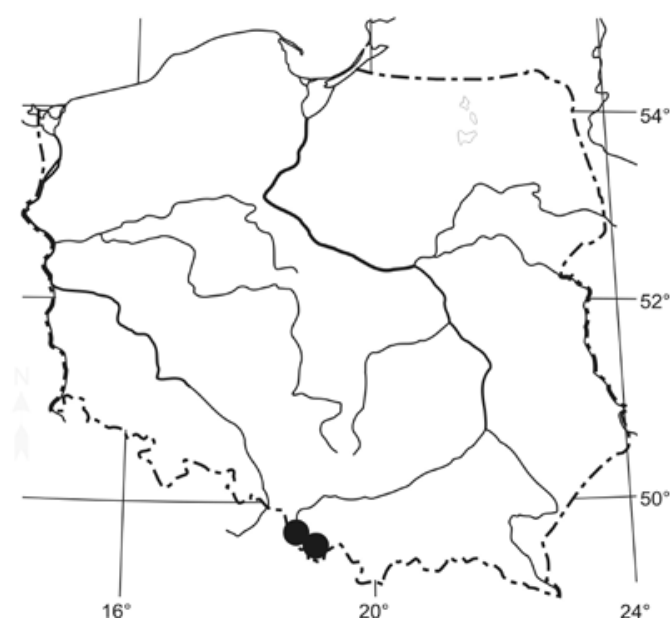

Fig. 1. Known distribution of Meottomyces dissimulans (Berk. \& Broome) Vizzini in Poland.

New localities of $M$. dissimulans were discovered during our recent field studies in southwestern Poland. These records are the first ones for $M$. dissimulans in Poland; they extend the distribution range of the species to this country, where $M$. dissimulans probably is under-recorded rather than rare. The presented description of basidiocarp morphology and ecological notes are based on original material.

\section{MATERIAL AND METHODS}

The specimens were collected occasionally during several field trips in different parts of southwestern Poland in 2012. The macroscopic features were studied from fresh material of two collections comprising 10 basidiomata in different stages of development. Microcharacters were observed with a Nikon Eclipse E-400 light microscope fitted with a Nikon digital camera (DS-Fi1). All microscopic structures were observed in dried material. Freehand sections of rehydrated pieces of basidiomata were examined in $5 \% \mathrm{NH}_{3} \cdot \mathrm{H}_{2} \mathrm{O}$ and Congo red reagent. Image-grabbing and biometric analyses were done with NIS-Elements D 3.1 imaging software. The dimensions of microcharacters are given as (minimum) average \pm standard deviation (maximum), and additionally as main data range (10-90 percentile values). The $Q$ value is the length/width ratio of basidiospores. For basidiospore size measurements, randomly selected mature spores from the lamella surface were measured without the hilar appendix. The length of basidia was 

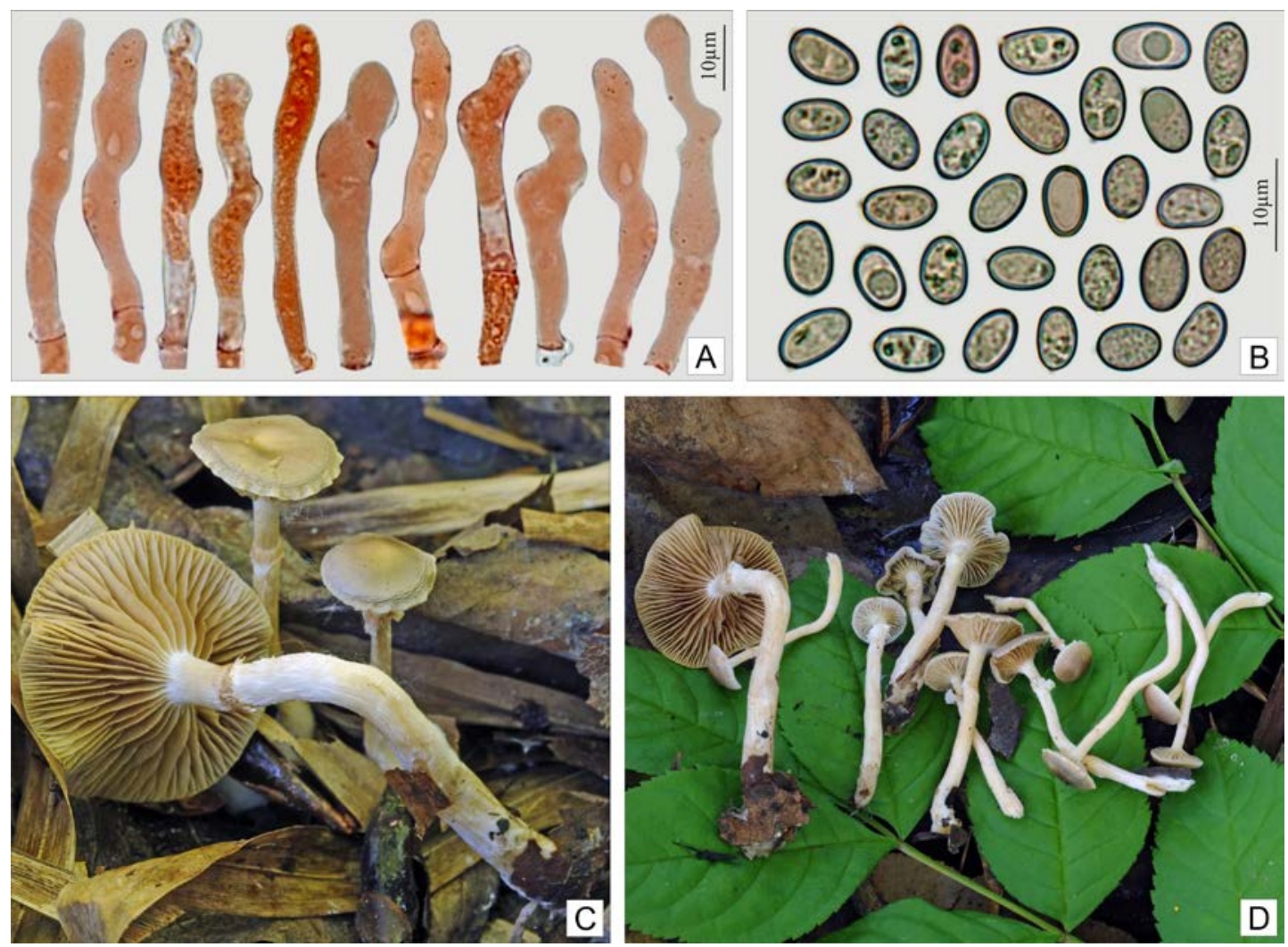

Fig. 2. Meottomyces dissimulans (Berk. \& Broome) Vizzini. A - cheilocystidia, B - basidiospores, C \& D - top, side and bottom views of basidiomata (all photographed from WRSL RyR-2012-0001).

measured excluding sterigmata. Micrographs were taken using a Nikon digital camera (DS-Fi1). Statistical computations employed Statistica (StatSoft). Morphological terminology follows Vellinga (1988) and Vellinga and Noordeloos (1999). Fungus nomenclature and synonyms follow Holec (2003), Moreau (2009) and Noordeloos (2011). The studied collections are deposited in the $\mathrm{Mu}-$ seum of Natural History, Wrocław University, Wrocław, Poland (WRSL).

\section{RESULTS}

\section{Meottomyces dissimulans (Berk. \& Broome) Vizzini Figs $1 \& 2$}

Riv. Micol. 51(1): 63. 2008. - Agaricus dissimulans Berk. \& Br., Ann. Mag. Nat. Hist., Ser. 5(9): 178. 1882 (for complete synonymy see Holec 2003).

ILLUSTRATIONS: Rald (1992: 5, fig. 2), Breitenbach and Kränzlin (1995: 341, fig. 436), Noordeloos (1999:
102, fig. 80), Ludwig (2000: 147, plate 145, fig. 30A, 2001: 552), Gminder (2003: 388, upper photo), Cetto (2006: 255, no. 1856, left photos), Roux (2006: 716, photo \& fig.), Vizzini et al. (2006: 69, fig. 2-3; 75, fig. 1), Noordeloos (2011: 409, plate 43, fig. 112), Læssøe and Petersen (2012: photo of Phaeogalera dissimulans), Legon (2013: 3, fig. 1; 4, fig. 2).

Basidiomata solitary, gregarious or subfasciculate. Pileus 5-30 mm, initially hemispherical, than convex with a slightly deflexed margin, after which plano-convex to applanate, hygrophanous, translucently striate up to $1 / 3-1 / 2$ of the radius in some basidiomata, young dark brown, later becoming yellow-brown with grey tinge to pale olivaceous-brown (strongly pallescent on drying), paler at margin, initially greasy to viscid, smooth, at margin with white velar remnants. Lamellae, $\mathrm{L}=20-35,1=1-4$, broadly adnate with decurrent tooth, segmentiform to subventricose, initially 
whitish cream when very young, then pale greyish cream, pale grey-brown, and finally pale brownish, with white fimbriate or flocculose edge. Stipe $15-40 \times 3.0-5.0 \mathrm{~mm}$, cylindrical, generally \pm swollen to bulbous towards base, white to pale ochreyellow, with fibrillose annulus or annuliform zone, pruinose above annulus, fibrillose-striate with white fibrils below, solid when young, becoming hollow when older. Context concolorous with surface in cortex, pallid in inner part of pileus and stipe. Smell indistinct. Taste not verified. Spore print dull yellow-brown.

Basidiospores (5.4) $7.5 \pm 0.7$ (9.9) $\times(3.7) 4.8$ $\pm 0.3(5.8) \mu \mathrm{m}, 6.6-8.6 \times 4.3-5.4 \mu \mathrm{m}, \mathrm{Q}=(1.2)$ $1.6 \pm 0.1(2.1), \mathrm{Q}=1.3-1.8, \mathrm{n}=212$, ellipsoidoblong (infrequently with adaxial side slightly less convex than abaxial side), faintly ovoid to slightly phaseoliform in side view, likewise in frontal view, with small hilar appendix, smooth, thin- to rather thick-walled, not dextrinoid, yellowish-greyish to pale yellowish ochre in ammonia, without or with indistinct germ pore. Basidia (22.4) $27.5 \pm 2.9$ $(35.2) \times(6.3) 7.6 \pm 0.7(9.7) \mu \mathrm{m}, 23.3-34.2 \times$ $6.8-8.8 \mu \mathrm{m}, \mathrm{n}=98$, narrowly clavate, $4-$ spored. Cheilocystidia (28.6) $44.3 \pm 9.9(73.0) \times(4.6) 6.6$ $\pm 0.9(9.1) \mu \mathrm{m}, 29.6-61.4 \times 5.3-8.2 \mu \mathrm{m}, \mathrm{n}=110$, flexuous-subcylindrical, cylindrical to narrowly clavate, frequently multiseptate, often with several constrictions and/or subcapitate apex, rarely with short obtuse protuberance at apex, thin-walled. Pleuro- and chrysocystidia absent. Pileipellis an ixocutis made up of narrow, cylindrical, 2-4 $\mu \mathrm{m}$ wide hyphae embedded in a gelatinous layer. Stipitipellis a cutis of 3.5-7.0 $\mu \mathrm{m}$ wide, cylindrical hyphae. Pigment pale yellow-brownish, parietal and slightly incrusting in upper layers of pileus and stipe. Caulocystidia present only at apex of stipe, scattered, similar to cheilocystidia, but more polymorphic (not measured). Clamp-connections abundant in all tissues.

SPECIMENS EXAMINED: POLAND. SilESIAN UPLAND. Ustroń, Katowicka Street, road verge planted with poplars, rotten leaves and twigs of Populus $\times$ canadensis, alt. $348 \mathrm{~m}$ a.s.1., $49^{\circ} 43^{\prime} 45^{\prime \prime} \mathrm{N}, 18^{\circ} 47^{\prime} 37^{\prime \prime} \mathrm{E}, 18$ June 2012, leg. R. Rutkowski (WRSL RyR-2012-0001); Żywiec Basin: Cisiec near Węgierska Górka, riparian forest (Alnetum incanae) along bank of Soła River, rotten twigs of broad- leaved trees (Alnus incana, Salix sp.), alt. $418 \mathrm{~m}$ a.s.1., $49^{\circ} 35^{\prime} 37^{\prime \prime} \mathrm{N}, 19^{\circ} 5^{\prime} 57^{\prime \prime} \mathrm{E}, 5$ Sep. 2012, leg. R. Rutkowski (WRSL RyR-2012-0002).

REMARKs. In general, the macro- and microscopic features of the examined Polish specimens of Meottomyces dissimulans are characteristic of the species, and their parameters (e.g., basidiocarp size and color, measurements and shape of basidiospores and cheilocystidia) are within the ranges reported by other authors (e.g., Noordeloos 1999, 2011). From the Polish records it is clear that $M$. dissimulans prefers deciduous dead twigs and rotten leaves (chiefly of Populus and Alnus) on rather rich and moist soil. This preference is frequently mentioned in the available data and coincides with remarks in the literature (e.g., Noordeloos 2011; Vesterholt 2012).

Acknowledgements. We are grateful to Bernadeta Pawlik (Cracow, Poland) and Dr. Jan Holec (Prague, Czech Republic) for their kind help in completing the mycological literature, and the anonymous reviewers for helpful remarks on the manuscript. This work was supported in part by the statutory fund of the Museum of Natural History of Wrocław University.

\section{REFERENCES}

Anonymous 2012. The Danish Red Data Book. [October 2015] http://www2.dmu.dk/1_Om_DMU/2_Tvaer-funk/3_fdc bio/projekter/redlist/artsgrupper_en.asp.

Antonín V., Beran M., Bieberová Z., BorovičKa J., Burel J., Čížek K., Deckerová H., DvořáK D., Graca M., Holec J., Hrouda P., Janda V., Jindřich O., Kotlaba F., PouZAR Z., SvrČEK M., ŠUtara J., VAMPOla P., VAŠUtová M., VÁGner A., ZelenÝ L. \& Zíta V. 2006. Výsledky: Stopkovýtrusné houby (oddelení Basidiomycota, tř́ida Agaricomycetes). In: J. Holec \& M. Beran (eds), Červený seznam hub (makromycetů) České republiky, pp. 1-282. Př́roda, 24. Agentura ochrany prŕrody a krajiny ČR, Praha.

Arnolds E. \& Veerkamp M. 2008. Basisrapport Rode Lijst Paddenstoelen. Nederlandse Mycologische Vereniging, Utrecht.

Berkeley M. J. \& Broome C. E. 1882. XXI. - Notices of British fungi. Ann. Mag. Nat. Hist. 9: 176-183.

Bon M. 1986. Novitates. Validations et taxons nouveaux. Doc. Mycol. 17: 51-56.

BreItenbaCh J. \& KräNZlin F. 1995. Fungi of Switzerland. 4. Agarics (Part 2). Verlag Mykologia, Luzern.

Cetto B. 2006. I funghi dal vero. 5. $3^{\text {ed }}$. Arti Grafiche Saturnia, Trento.

Courtecuisse R. \& Duhem B. 2007. Guide des champignons de France et d'Europe. Delachaux et Niestlé, Paris. 
Garnica S., Weiss M., Walther G. \& Oberwinkler F. 2007. Reconstructing the evolution of agarics from nuclear gene sequences and basidiospore ultrastructure. Mycol. Res. 111(9): 1019-1029.

Gminder A. 2003. Strophariaceae Singer \& Smith. In: G. J. Krieglsteiner (ed.), Die Großpilze Baden-Württembergs. 4. Ständerpilze: Blätterpilze. II, pp. 346-426. Verlag Eugen Ulmer GmbH \& Co., Stuttgart.

Hagara L. 2014. Ottova encyklopédia húb. Ottovo Nakladatel'stvo, Praha.

Hausknecht A. 1992. Fundliste der 20 Mykologischen Dreiländertagung in Korneuburg 1990. Österr. Z. Pilzk. 1: 61-69.

HoleC J. 2003. Taxonomy and nomenclature of Pholiota dissimulans with respect to Phaeogalera oedipus. Sydowia 55: 77-85.

Kalamees K. 1985. Phaeogalera oedipus (Cooke) Romag. in the U.S.S.R. Folia Cryptog. Estonica 18: 1-8 (in Russian with English summary).

KüHNER R. \& Romagnesi H. 1953. Flore analytique des champignons supérieurs (Agarics, Bolets, Chanterelles) comprenant les espčces de l'Europe occidentale et centrale ainsi que la plupart de celles de l'Algérie et du Maroc. Masson et Cie, Paris.

Læssøe T. \& Petersen J. H. 2012. MycoKey 4.0 - an interactive identification system to fungal genera. http://www. mycokey.com

Legon N. 2013. Fungal Portaraits No. 49: Meottomyces dissimulans. Field Mycology 13(1): 3-7.

Ludwig E. 2000. Pilzkompendium. Band 1: Abbildungen. Die kleineren Gattungen der Makromyzeten mit lamelligem Hymenophor aus den Ordnungen Agaricales, Boletales und Polyporales. IHW-Verlag, Eching.

Ludwig E. 2001. Pilzkompendium. 1: Beschreibungen. Die kleineren Gattungen der Makromyzeten mit lamelligem Hymenophor aus den Ordnungen Agaricales, Boletales und Polyporales. IHW-Verlag, Eching.

Malençon G. \& Bertault R. 1970. Flore des champignons supérieurs du Maroc. 1. Trav. Inst. Sci. Chérifien, Sér. Bot. Biol. Vég. 32: 1-601.

Marchand A. 1980. Champignons du Nord et du Midi. 6: Lactaires et Pholiotes. Société Mycologique des Pyrénées Méditerranéennes, Perpignan.

Moncalvo J.-M., Vilgalys R., Redhead S. A., Johnson J. E., James T. Y., Catherine Aime M., Hofstetter V., Verduin S. J. W., Larsson E., Baroni T. J., Greg Thorn R., JACOBSSON S., Clémençon H. \& Miller JR. O. K. 2002. One hundred and seventeen clades of euagarics. Molec. Phylogen. Evol. 23(3): 357-400.

Moreau P.-A. 2009. Révision des naucorioideae, geophileae et cortinarieae naucoriod'des Flore des Champignons Supérieurs du Maroc. I. In: J.-C. MaIre, P.-A. MoreaU
\& G. RoBICH (eds). Compléments $\dot{r}$ la flores des champignons supérieurs de Maroc de G. Malençon et R. Bertault, pp. 161-204. Confédération Européenne de Mycologie Méditerranéenne, Nice.

NAGY L. G. 2004. Fungistical investigations in the Great Hungarian Plain from 1996 to 2003. Mikol. Közlem. 43(1-3): 15-46 (in Hungarian with English summary).

Noordeloos M. E. 1999. Family Strophariaceae. In: C. BAS, T. W. Kuyper, M. E. Noordeloos \& E. C. Vellinga (eds), Flora Agaricina Neerlandica. 4: 27-107. A. A. Balkema Publishers, Rotterdam.

Noordeloos M. E. 2011. Strophariaceae s.l. Fungi Europaei. 13. Edizioni Candusso, Alassio.

ONOFri S. (ed.) 2005. Checklist dei funghi italiani. Basidiomycetes. Carlo Delfino, Sassari.

Ortega A. \& Esteve-Raventós F. 1998. Contribution to the study of the mycoflora of Andalusia (Spain) XIII. Agaricales VI. Taxonomic notes on two interesting Agarics from the Iberian Peninsula. Nova Hedwigia 67(1-2): 107-113.

Petersen G., Knudsen H. \& Seberg O. 2010. Alignment, clade robustness and fungal phylogenetics - Crepidotaceae and sister families revisited. Cladistics 26(1): 62-71.

RALD E. 1992. To for Danmark nye arter af Skælhat (Pholiota squarrosoides og Pholiota oedipus). Svampe 26: 3-5.

Romagnesi H. 1980. Position taxonomique de l'Agaricus oedipus Cooke. Bull. Soc. Mycol. France 96(3): 249-251.

Roux P. 2006. Mille et un champignons. Édition Roux, SainteSigolène.

Senn-Irlet B., Bieri G. \& EGLi S. 2007. Rote Liste der gefährdeten Grosspilze der Schweiz. Umwelt-Vollzug Nr. 0718. Bundesamt für Umwelt BAFU und der Eidgenössischen Forschungsanstalt für Wald, Schnee und Landschaft WSL, Bern, Birmensdorf.

Smith A. H. \& Hesler L. R. 1968. The North American Species of Pholiota. Hafner, New York.

Tholl M.-T. 2010. Notes mycologiques (1986-1995). Bull. Soc. Naturalistes Luxemb. 97: 119-134.

Vellinga E. C. 1988. Glossary. In: C. Bas, T. W. Kuyper, M. E. Noordeloos \& E. C. Vellinga (eds), Flora Agaricina Neerlandica. 1: 54-64. A. A. Balkema Publishers, Rotterdam.

Vellinga E. C. \& Noordeloos M. E. 1999. Glossary. In: C. Bas, T. W. Kuyper, M. E. Noordeloos \& E. C. Vellinga (eds), Flora Agaricina Neerlandica. 4: 6-12. A. A. Balkema Publishers, Rotterdam.

Vesterholt J. 2012. Meottomyces Vizzini. In: H. Knudsen \& J. Vesterholt (eds), Funga Nordica. Agaricoid, boletoid, clavarioid, cyphelloid and gastroid genera, pp. 948 \& 950. Nordsvamp, Copenhagen.

Vizzini A. 2008. Novitates. Miscellanea. Riv. Micol. 51(1): 63-66. 
Vizzini A., Perić B. \& Cacialli G. 2006. Phaeogalera dissimulans (Berk. \& Broome) Holec, una nuova entità per la micoflora montenegrina. Mycol. Montenegrina 9: 65-79.

Walleyn R., Antonissen I., de HaAn A., de HaAn M., de Keyser J., Hendrickx H., Lachapelle J., Le Jeune G., Mervielde H., Noten L., Schoutteten J., van de KercKhove O., van de Put K., Verbeken A., Volders J., Lenaerts L., Monnens J., Termonia W., Van der Veken P., Van Ryckegem G., Vandeven É., Beker H., Bogaerts A., De Kesel A., De Pauw S., Dielen F., Ghyselinck D.,
HANSSENS C. \& VANNIEUWERBURGH L. 2006. Standaardlijst van Basidiomycota en Myxomycota van Vlaanderen en het Brussels Gewest. In: R. WALLeyn \& É. VANDEVEN (eds), Standaardlijst van Basidiomycota en Myxomycota van Vlaanderen en het Brussels Gewest. Rapport INBO.R.2006.27, pp. $1-143$ + errata. Instituut voor Natuur- en Bosonderzoek, Brussel.

Walther G., Garnica S. \& Weiss M. 2005. The systematic relevance of conidiogenesis modes in the gilled Agaricales. Mycol. Res. 109(5): 525-544.

Received 2 April 2015 